\title{
Herbert Marcuse, Paulo Freire e a economia solidária como alternativa emancipatória*
}

\author{
Daniel Calbino ${ }^{l}$ \\ Ana Paula Paes de Paula ${ }^{2}$ \\ Universidade Federal de Minas Gerais
}

O presente artigo visou compreender porque as tentativas de revoluções de caráter socialista "fracassaram", utilizando como referência as concepções de Marcuse e Freire. Para realizar esta tarefa recorremos principalmente à análise das obras Eros e civilização de Marcuse (1968) e Pedagogia do oprimido de Freire (2006b). Constatamos algumas similaridades nas perspectivas destes autores. Marcuse (1968) recorreu às teorias psicanalíticas de Freud para compreender este fenômeno, e concluiu que a causa é a repressão das pulsões de vida (Eros) que gera indivíduos aptos a aceitarem uma sociedade repressiva e a temerem sua libertação. Freire (2006b), por sua vez, partiu da premissa de que os oprimidos carregam dentro de si o opressor, reproduzindo suas atitudes e comportamentos quando chegam ao poder, pois temem a liberdade de preencher o vazio deixado pela expulsão do opressor. Para sanar estes problemas, Marcuse (1968) pregava a luta pela redução do trabalho alienado, e Freire (2006b) a busca por uma educação dialógica entre o educando e o educador.

This paper aimed to understand why the attempts of revolution socialist "have failed", using as reference the ideas of Marcuse and Freire. To accomplish this analysis was used the work Eros and civilization Marcuse (1968) and Pedagogy of the oppressed Freire's (2006b). We found some similarities in the perspectives of these authors. Marcuse (1968) drew on psychoanalytic theories of Freud to understand this phenomenon, and concluded that the cause is the repression of the instincts of life (Eros) that generates individuals able to accept a repressive society and with fear of his release. Freire (2006b), in turn, started from the premise that the oppressed carries within it the oppressor, reproducing their attitudes and behaviors when to comes to power, because they fear freedom to fill the void left by the expulsion of the oppressor. To remedy these problems, Marcuse (1968) preached, the struggle for reduction of alienated labor, and Freire (2006b) a dialogue between who teach and who learn. After the exhibition and interpretation of the readings of the two authors,

\footnotetext{
${ }^{*}$ Herbert Marcuse, Paulo Freire and solidary economy as an emancipatory way.

${ }^{1}$ Mestre em Administração e Doutorando em Administração (UFMG). Professor Assistente do IFMG. Endereço para correspondência: Rua Professor Nelson de Sena, 115, apto. 34, Aeroporto, Belo Horizonte, MG, 31270-660 (dcalbino@yahoo.com.br).

${ }^{2}$ Mestre em Administração (FGV-SP) e Doutora em Sociologia (Unicamp). Professora Adjunta da UFMG. Endereço para correspondência: Avenida Antonio Carlos, 6627, sala 4033, Pampulha, Belo Horizonte, MG, 21260-901 (appaula@,face.ufmg.br).
} 


\section{HUMANAS}

Depois da exposição e interpretação das leituras dos dois autores, apresentamos a Economia Solidária como um cenário para a implementação das saídas sugeridas por Freire (2006b) e Marcuse (1968), o que a torna uma possível nova via revolucionária.

Palavras-Chave: Economia solidária-Revolução - Herbert Marcuse - Paulo Freire we present the Solidarity Economy as a backdrop for the implementation of the outputs suggested by Freire (2006b) and Marcuse (1968), which become a possible way to revolution.

Keywords: Solidary economy - Revolution - Herbert Marcuse - Paulo Freire

\section{Introdução}

presente ensaio teórico tem por objetivo compreender, sob a ótica de Herbert Marcuse e Paulo Freire, os motivos que conduziram ao "fracasso" as revoluções de caráter socialista ${ }^{3}$, bem como avaliar o potencial da Economia Solidária enquanto alternativa emancipatória na medida em que esta se alinha com as recomendações destes autores para empreender a revolução.

Em seu livro Eros e civilização, Marcuse (1968) aponta que a causa da instituição da nova opressão é a interiorização instintiva do velho domínio. Este autor se fundamenta nas teorias freudianas, e argumenta que a dominação tornou-se algo interiorizado, pois o próprio sujeito acaba por apoiar os senhores e suas instituições. Essa aceitação de uma sociedade opressiva decorre da repressão das pulsões de vida (Eros) e do temor de sua própria libertação (LOUREIRO, 2005). Uma alternativa, então, seria a conversão dos impulsos reprimidos em impulsos de vida, o que seria materializado com a redução do trabalho alienado. É valido destacar o contexto que influenciou Marcuse, que foi o pós-guerra, momento no qual as tentativas de revolução tinham sido derrotadas: nos EUA emergiam o consumo de massa, o welfare state e a guerra fria, e o projeto socialista da URSS não representava uma alternativa emancipatória real. Ao estudar Freud, este autor deduziu que sem compreender como funciona a subjetividade humana, a revolução seria ineficaz. E que uma revolução bem sucedida deveria se centrar não apenas nas transformações radicais das bases materiais da sociedade, mas também na emancipação dos sentidos e na transformação radical da consciência e do inconsciente (LOUREIRO, 2005).

\footnotetext{
${ }^{3}$ Ao se referir ao fracasso das revoluções socialistas, não se nega as contribuições que estas tentativas geraram para a sociedade. O fracasso aqui se entende pela impossibilidade das mudanças estruturais e culturais de caráter amplo e global, na qual se propuseram.
} 


\section{Herbert Marcuse, Paulo Freire e a economia solidária como alternativa emancipatória}

Em Pedagogia do oprimido, Freire (2006b) demonstra que o "fracasso" das revoluções se deve à premissa de que os oprimidos carregam dentro de si o opressor. Os oprimidos introjetam a sombra dos opressores e temem a liberdade. Destarte, seguem a pauta dos antigos opressores para manutenção da ordem vigente. A alternativa para superar a dialética oprimido-opressor é a educação, que não se limita apenas em mostrar ao oprimido que este carrega também um opressor, mas que se manifesta de uma forma orgânica, de forma que o educador educa com e não para o educando.

Neste sentido, a Economia Solidária pode ser uma via para implementar a proposta de Marcuse (1968), que seria o fim do trabalho alienante, ou melhor, a sua redução, possibilitando a libertação do Eros, associada à proposta de Freire (2006b), que prevê uma educação do oprimido, que se realize de maneira democrática e dialética entre o educador e o educando. Defendemos a tese de que a Economia Solidária pode se alinhar com os princípios básicos de um projeto socialista, pois se baseia na mudança da propriedade dos meios de produção, na gestão democrática desses meios e na orientação da produção para a satisfação das necessidades humanas. $\mathrm{O}$ formato cooperativista incentivado pela Economia Solidária se apresenta como um contraponto à lógica do capital, na medida em que se funda nos valores de solidariedade e coletivismo e se estrutura por meio de uma mudança organizacional que prevê uma socialização dos ganhos e decisões coletivas.

Reconhecemos que em um meio permeado pela lógica do capital, há o risco de tais formatos continuarem reproduzindo as estrutura de alienação e dominação e por este motivo também defendemos a estruturação destas cooperativas por meio de redes solidárias e integradas, que permitam o controle global do processo de trabalho pelos cooperados. É verdade que há limites nesta alternativa, mas ela propicia uma possível redução da alienação no trabalho, como proposta por Marcuse (1968) e cria um ambiente favorável para educação dialógica proposta por Freire (2006b), na medida em que se baseia em valores solidários, denuncia desigualdades sociais, critica a lógica de produção e consumo do sistema capitalista, ressignifica os modelos de gestão de modo a adequá-los à autogestão e incentiva a autocrítica do próprio sistema sócio-político vigente.

Para desenvolver esta argumentação, apontando a Economia Solidária como uma possível alternativa emancipatória, na primeira parte do artigo, discutiremos as críticas de Marcuse às revoluções socialistas e o que ele considera as bases da opressão, partindo do pensamento freudiano. Na segunda parte, nos deteremos no pensamento de Paulo Freire, que de maneira análoga faz sua crítica à burocratização das revoluções e aponta que o oprimido é hospedeiro da opressão, de modo que somente uma educação dialógica poderia promover uma ruptura com a tendência de perpetuar a lógica de dominação. 


\section{HUMANAS}

Na terceira parte, abordaremos as definições de Economia Solidária, suas formas de organização e a arquitetura de um projeto alternativo alinhado às proposições de Marcuse e Freire. Nas considerações finais, apresentamos uma síntese de nossa discussão e os limites da proposta apresentada.

\section{Herbert Marcuse ${ }^{4}$ e Eros e Civilização}

\subsection{A origem das revoluções traídas}

[...] É ridículo e talvez "lógico" que o Movimento pela Liberdade de Expressão, em Berkeley, terminasse em balbúrdia e brigas entre os participantes, por causa do aparecimento de um cartaz com um palavrão (MARCUSE, 1968; p. 20).

Esta passagem é uma clássica descrição do desfecho das revoluções, nas quais, na maioria das vezes, a derrocada do poder, e a consequente assunção de uma nova classe, transfiguram-se em "neo-repressão", ou seja, em atitudes semelhantes ou piores de repressão, que até então eram condenadas. Buscando compreender esse fenômeno, Marcuse (1968) se vale das teorias de Freud ${ }^{5}$ a fim de alcançar uma explicação para a paradoxal - e irônica - instituição de um novo poder tão ou mais opressivo do que o anterior, assim como para tentar discorrer sobre as origens, causas e processos que conduzem às atitudes repressivas.

Como se pode observar, o ponto nevrálgico do "fracasso" de uma revolução é a perpetuação da opressão e repressão. Estas, segundo o autor são um fenômeno histórico, sendo impostas não pela natureza, mas pelo homem.

\footnotetext{
${ }^{4}$ Pensador norte-americano, de origem alemã, nascido em 1898, em Berlim, e falecido em 1979 Formado em 1922 pela Universidade de Freiburg, tornou-se militante do Partido Social Democrático. Tendo sido um dos fundadores do Instituto de Pesquisas Sociais (Escola de Frankfurt), foi para a Suíça quando Hitler ascendeu ao poder, adotando a nacionalidade norte-americana em 1940. O seu pensamento teve como ponto de partida a dialética de Hegel e a filosofia de Heidegger, e contribuiu para influenciar a rebelião estudantil de 1968. Condenou o marxismo soviético, denunciou o caráter repressivo da sociedade industrial e pregou transformações revolucionárias tanto nas instituições sociais como nas atitudes humanas. Defendia que o Homem deveria libertar-se, inclusive pela sexualidade, das convenções e condicionamentos que o dominam. Entre as suas obras de destacam-se Eros e civilização (1955), O homem unidimensional (1964) e Contra revolução e revolta (1972).

${ }^{5}$ Sigmund Freud nasceu em 1856 na antiga Tchecoslovaquia, graduou-se em Medicina com enfoque na área de Psiquiatria. Ao se deparar com pacientes com histeria, observou que se tratava de uma doença vinculada a fatores psicológicos. Para compreender esses fenômenos criou um método substituindo a hipnose pela psicanálise. Com o enfoque nos fatores psicologicos, seus estudos questionaram tabus culturais, sociais, religiosos e científicos. Na obra Totem e Tabu o autor constrói uma reflexão a respeito da dominação, presente desde a origem da civilização, como será abordado nas citações de Herbert Marcuse.
} 


\section{Herbert Marcuse, Paulo Freire e a economia solidária como alternativa emancipatória}

Recorrendo às teorias psicanalíticas de Freud sobre a origem da civilização, constata-se que tal fenômeno ocorre por meio do domínio imposto de um indivíduo sobre os outros: o pai, personificado na figura do chefe do clã. Devido ao tabu do incesto, que proibia que os homens se relacionassem sexualmente e casassem com as mulheres do mesmo clã, pois todos seus membros são considerados irmãos consangüíneos e chamam de pai e mãe a todos os homens e mulheres que poderiam tê-los gerado. Esta proibição é reforçada pela crença de que uma maldição sobreviria sobre aquele que desrespeitasse o tabu.

A aceitação desta proibição se justificava pela proteção, segurança e até amor. Em virtude do déspota ser personificado na figura do pai, a aversão com que os membros do clã o viam, era acompanhada pelo desejo de substituir o pai, de se identificarem com ele e com o seu poder, de impor o tabu. Tal atitude, a repressão da gratificação das necessidades instintivas imposta pelo pai - a supressão do prazer - não foi apenas um fator de dominação, mas criou também precondições mentais que eram propícias ao contínuo funcionamento da dominação, como será visto em seguida.

Num certo momento, quando a efetividade da organização imposta pelo pai ao grupo começa a se enfraquecer e o ódio contra a supressão patriarcal aumenta, ocorre a revolta. Esse ódio culmina na rebelião dos filhos que assassinam e promovem a devoração coletiva do pai, estabelecendo o clã dos irmãos. Contudo tal rebelião destrói a ordem que preservava a vida no grupo, e isto gera um sentimento de culpa, de crime contra o todo, e por conseguinte, contra eles próprios. Na busca de uma duradoura satisfação das suas necessidades, o clã então encontra a saída, a restauração das atitudes do pai, e para isso todos os membros começam a respeitar e reproduzir os tabus que foram impostos pelo mesmo, mantendo a dominação patriarcal (MARCUSE, 1968).

Segundo o autor, esse processo é um ciclo recorrente de "dominaçãorebelião-dominação", no qual a segunda rebelião não é simplesmente repetição da primeira, mas um movimento em progresso da dominação.

\subsection{O progresso da dominação}

A concepção de que existe um progresso da dominação neste ciclo, ocorre no momento em que o pai estabeleceu a ordem, de maneira "racional". Dessa forma, ele criou, preservou o grupo e preparou o terreno para o progresso através da repressão que gera a abstinência forçada e suprime o prazer, criando assim as primeiras condições para a disciplinada força de trabalho do futuro. Para o autor, partindo do pai primordial, passando pelo clã fraterno, até atingir o sistema de autoridade institucionalizada, característico da sociedade moderna, a dominação torna-se cada vez mais racional, eficaz e produtiva. 


\title{
HUMANAS
}

Nesse processo, a repressão é despersonalizada, pois a restrição e arregimentação do prazer passam agora a ser uma função da divisão social do trabalho.

\begin{abstract}
O respeito e o medo podiam, portanto, ser acompanhados pelo ódio ao que eles eram e faziam como pessoas; apresentavam um objeto vivo como alvo dos impulsos e dos esforços conscientes para satisfazê-los. Mas essas imagens do pai pessoal desapareceram gradualmente atrás das instituições. Com a racionalização do mecanismo produtivo, com a multiplicação de funções, toda a dominação assume a forma de administração (MARCUSE, 1968; p. 98).
\end{abstract}

Neste momento, a busca pela eficiência e pelo desempenho da sociedade trás consigo uma subordinação efetivada por meio da divisão social do trabalho e da hierarquia de funções. A partir desse princípio do desempenho, a dominação e a alienação são derivadas da organização social predominante do trabalho, levando assim à repressão do homem. Por isso, os homens não vivem sua própria vida, mas desempenham tão somente funções pré-estabelecidas. Enquanto trabalham, não satisfazem suas próprias necessidades, mas trabalham em alienação. $\mathrm{O}$ tempo do trabalho ocupa a maior parte do tempo de vida de um indivíduo, e este trabalha somente na medida em que o faz para o sistema, se empenhando em atividades que não coincidem com suas faculdades e desejos (MARCUSE, 1968).

A felicidade então poderia ocorrer nos escassos momentos de tempo livre. Contudo, o indivíduo, mesmo em seu tempo livre, acaba desempenhando comportamentos em conformidade com os padrões e a moral do princípio do desempenho imposto na sociedade. Isto é dirigido pelas técnicas de manipulação das massas que criou uma indústria de entretenimentos, a qual controla o tempo e o lazer do indivíduo (MARCUSE, 1968; ADORNO, 1978; BENJAMIN, 1982; HORKHEIMER \& ADORNO, 2007).

Marcuse (1968) relata que em troca de artigos que supostamente enriquecem a vida, os indivíduos vendem não só o seu trabalho, mas também seu tempo livre. $\mathrm{O}$ autor diz que a vida melhor é contrabalanceada pelo controle total sobre a vida, na qual possuem geladeiras repletas de alimentos congelados, jornais e revistas que esposam os mesmos ideais, dispõem de opções e inventos que são da mesma espécie, que os mantêm ocupados e distraem sua atenção do problema: a consciência de que poderiam trabalhar menos e determinar suas próprias necessidades e satisfações.

A agressividade voltada contra o eu ameaça ficar sem qualquer sentido: com sua consciência coordenada, sua intimidade abolida, não dispõe mais de 


\title{
Herbert Marcuse, Paulo Freire e a economia solidária como alternativa emancipatória
}

\begin{abstract}
"espaço mental" suficiente para desenvolver-se contra o seu sentimento de culpa, para viver com uma consciência própria(MARCUSE, 1968; p. 98).
\end{abstract}

Nota-se então que antes os grupos que tinham alcançado a hegemonia reprimiam por medo de uma revolta dos oprimidos, de modo que a regulação social era ainda mais rigorosa. Com o progresso do capitalismo, a repressão passa a ocorrer por meio da incorporação dos credos políticos e econômicos pelos indivíduos, que passam a assimilar o discurso do consumo e do uso do tempo livre para o lazer disponível no mercado. Para terem estas benesses os indivíduos se sujeitam ao sistema hierárquico do trabalho, que fragmenta sua capacidade de pensar e agir, conduzindo-os a reproduzirem a própria opressão que sofrem.

Para o autor isto explica porque desde as revoltas dos escravos no mundo antigo à revolução social do nosso tempo, a luta dos oprimidos terminou no estabelecimento de um novo e melhor sistema de dominação. Marcuse (1968; p.92) ainda ressalta que, apesar disto, todas as revoluções tiveram seu momento de liberdade, embora este tenha passado:

\begin{abstract}
Em todas as revoluções parece ter havido um momento histórico em que a luta contra a dominação poderia ter saído vitoriosa... mas o momento passou. Um elemento de autoderrota parece estar em jogo nessa dinâmica. Nesse sentido, todas as revoluções foram também revoluções traídas.
\end{abstract}

\subsection{A alternativa pelo trabalho não alienado}

Diante destas considerações, infere-se que as revoluções caminham para uma situação cíclica caótica, que implica no aumento do poder, no progresso, e na repressão, levando ao "fracasso" todas as propostas de mudança que procuravam liberar os impulsos e desejos do homem. Qual seria então a saída para este problema? Onde encontrar o antídoto para combater o elemento de autoderrota que derrubou todas as propostas revolucionárias? Como lutar contra uma opressão que caminha cada vez mais para uma despersonalização do repressor e a conseqüente racionalização desse processo?

Marcuse (1968; p. 103) então parte da premissa de que a teoria da alienação demonstrou que o homem não se realiza em seu trabalho e que sua vida se tornou um instrumento de trabalho. $\mathrm{O}$ trabalho do homem e os seus respectivos produtos assumiram uma forma e um poder que se independeram dele enquanto indivíduo. Sendo este o ponto central, a idéia é que "não se impeça a alienação, mas que se consuma; não a reativação da personalidade reprimida e produtiva, mas a sua abolição". 


\title{
HUMANAS
}

A abolição do trabalho alienado permitiria investir a libido no trabalho que se tornaria assim um trabalho lúdico - e nas relações sociais, o que transformaria a vida em um jogo estético/erótico no qual os sentidos humanos não seriam mais moldados pela mercadoria. Numa sociedade não repressiva, a gratificação seria inerente a toda vida social e ocorreria a reconciliação entre os seres humanos e a natureza (LOUREIRO, 2005).

Para que isto ocorra o autor sugere que o combate à repressão e à alienação advenha da redução da divisão do trabalho e da ausência de uma especialização de funções institucionalizadas e hierárquicas. Ainda, faz-se necessário a permutabilidade de funções e a redução do tempo de trabalho a um mínimo.

\begin{abstract}
Como a duração do dia de trabalho é, por si mesma, um dos principais fatores repressivos impostos ao princípio de prazer pelo princípio de realidade, a redução do dia de trabalho a um ponto em que a mera porção do tempo de trabalho já não paralise o desenvolvimento humano é o primeiro pré-requisito a liberdade (MARCUSE, 1968; p. 141).
\end{abstract}

Partindo dessas propostas, o autor conclui apresentando a tese de que a porção de energia instintiva a ser ainda desviada pelo trabalho "necessário" (no caso, imposto ao trabalhador, sendo mecanizado e racionalizado), seria tão pequena, que uma vasta área de coerções e modificações repressivas, que não contariam mais com apoio de forças externas, entraria em colapso. Conseqüentemente, a relação antagônica entre o princípio do prazer e o princípio do desempenho (a lógica da racionalização) se alteraria em favor do primeiro e Eros (os instintos de vida) seria libertado de uma forma sem precedentes.

\section{Paulo Freire ${ }^{6}$ e a Pedagogia do Oprimido}

\subsection{0 "fracasso" das revoluções}

Raros são os camponeses que ao serem promovidos a capatazes, não se tornam mais duros opressores de seus antigos companheiros do que o patrão mesmo (FREIRE, 2006b; p. 36).

\footnotetext{
${ }^{6}$ Pedagogo brasileiro nascido em 1922 e falecido em 1997. Em 1964, iniciou um método de alfabetização de adultos nas regiões pobres do nordeste brasileiro. O seu projeto-piloto foi extinto nesse ano devido ao golpe militar, tendo como primeira conseqüência a prisão de Freire e mais tarde o seu exílio no Chile e na Suíça. Enquanto exilado, se tornou-se conhecimento internacionalmente no tema de alfabetização de adultos, tendo visto o seu método aplicado em diversos países. Especialmente apreciado foi o seu livro Pedagogia do oprimido (1970), em que defendia que educar não é transmitir conhecimentos, mas trocar experiências.
} 


\section{Herbert Marcuse, Paulo Freire e a economia solidária como alternativa emancipatória}

Ao se ler a citação acima um dos primeiros questionamentos que pode surgir é: por que os oprimidos quando chegam ao poder começam a repetir as atitudes de repressão dos opressores? No caso de uma revolução, porque os líderes quando chegam ao poder acabam tornando-se tiranos, ditadores, detentores da "verdade"?

Freire (2006b) tenta explicar tal fato partindo-se da premissa de que os oprimidos introjetam as atitudes dos opressores, seguindo suas pautas. Por isso, quase sempre, em um primeiro momento de uma revolução ou mudança, os oprimidos, ao invés de buscarem a libertação na luta e por ela, tendem a ser opressores também, ou sub-opressores. O autor ainda ressalta que a estrutura do seu pensar se encontra condicionada pela contradição vivida na situação concreta, existencial, em que se formam. Logo, "ser Homem", para eles, diante da contradição em que sempre estiveram e cuja separação não lhes é clara, é ser opressor.

Porém o que justifica o oprimido carregar o opressor dentro de si e continuar essa reprodução? O autor busca explicar que a causa repousa no medo da liberdade. Na medida em que o oprimido se libertasse do opressor que existe dentro dele, ele seria compelido a preencher o vazio deixado por essa expulsão com o conteúdo de sua autonomia. Com isso os oprimidos, acomodados e adaptados, imersos na própria engrenagem da estrutura dominadora, temem a liberdade, enquanto não se sentem capazes de correr o risco de assumi-la.

$\mathrm{O}$ autor ainda ressalta que a liberdade é uma conquista e não uma doação e isto exige uma permanente busca, que só existe no ato responsável de quem a faz. Ninguém tem liberdade para ser livre: pelo contrário, luta-se pela liberdade precisamente porque não a temos. A liberdade não é uma utopia inalcançável, mas uma condição indispensável ao movimento de busca em que estão inscritos os homens como seres inconclusos. Pode-se agora compreender o motivo do "fracasso" das revoluções sobre a perspectiva de Freire (2006b; p. 36):

Até as revoluções, que transformaram a situação concreta de opressão em uma nova, em que a libertação se instaura como processo, enfrentam esta manifestação da consciência oprimida. Muitos oprimidos que direta ou indiretamente, participaram da revolução, marcados pelos velhos mitos da estrutura anterior, pretendem fazer da revolução a sua revolução privada. Perdura neles, de certo modo, a sombra testemunhal do opressor antigo. Este continua a ser o seu testemunho de "humanidade".

A partir destas considerações Freire (1974, 1977, 1983, 2006a, 2006b) tenta analisar algumas atitudes dos revolucionários, que acabam fomentando a opressão e conseqüentemente anulando as propostas revolucionárias. 


\section{HUMANAS}

Dentre estas, o autor cita que a subestimação do conhecimento das massas, que decreta as massas como absolutamente ignorantes e os revolucionários como a classe que sabe ou nasceu para saber. Essa concepção de classe revolucionária-líder, que declara somente para si o domínio do saber, desencadeia: (1) o processo de educação bancária, (2) a revolução sem comunicações, (3) o uso de um mecanicismo e (4) a morte da autocrítica.

A educação bancária ocorre de maneira antidialética, na qual os educandos são os depositários e o educador depositante. Não existe diálogo entre eles. $\mathrm{O}$ educador é o detentor do conhecimento e os educandos apenas recebem o conhecimento, guardam e arquivam. Ainda, o educador se mantém em posição fixa, sendo sempre aquele que sabe, e os educandos, alienados, reconhecem em sua ignorância a razão da existência do educador. Não se questiona o que os educandos de fato querem aprender e não existe espaço para a troca de conhecimentos entre os dois. Esse processo ocorre não só na maior parte das escolas formais hoje, como também alimentou a lógica do Partido Comunista na URSS, que tomava as decisões em nome das massas, sob a alegação de serem detentores dos conhecimentos das necessidades sociais. Freire (2006a, 2006b, p. 143) cita este problema na seguinte passagem:

O que não se pode realizar, na práxis revolucionária, é a divisão absurda entre a práxis da liderança e a das massas oprimidas, de forma que a destas fosse a de apenas seguir as determinações da liderança. Esta dicotomia existe, como condição necessária, na situação de dominação, em que a elite dominadora prescreve e os dominados seguem as prescrições.

A revolução sem comunicação ocorre quando, ainda que munido de boas intenções, mas de maneira equivocada, o processo de diálogo entre lideranças e massas torna-se demorado e, em busca da eficiência, faz-se a revolução, sem comunicação, por meio dos comunicados. Afirma-se que depois de realizada a revolução, é que se buscará desenvolver um amplo esforço educativo. Tal atitude de evitar o diálogo causa uma centralização, permitindo que o poder revolucionário se institucionalize e se estratifique em uma burocracia. Conseqüentemente, transforma os revolucionários em reacionários (FREIRE, 1983, 2006b).

Já o mecanicismo ocorre exatamente no momento em que os revolucionários acreditam que as massas são classes dominadas, que estão soltas como objetos para serem libertadas por eles, que se acreditam sujeitos da ação revolucionária. O processo de libertação é para eles algo mecânico. 


\section{Herbert Marcuse, Paulo Freire e a economia solidária como alternativa emancipatória}

Daí o seu voluntarismo. Daí a sua confiança mágica na ação militar dicotomizada da ação política. Daí lhes sejam mais fácil realizar mil ações arriscadas, mesmo sem significação política, do que conversar com um grupo de camponeses durante 10 minutos (FREIRE, 1977; p. 139).

Por fim, o problema da morte da autocrítica, que ocorre nos partidos e movimentos revolucionários, leva, em muitos casos, aos burocratismos que implicam novas formas de opressão e de invasão. E isto acontece no momento em que se nega a dialética entre os revolucionários e a classe dominada (FREIRE, 1997, 2006b).

\subsection{A alternativa pela via da educação}

Diante dos problemas que ocorrem nas ações revolucionárias, minandoas, Freire (2006a, 2006b, p. 58) propõe como alternativa a adoção do processo de educação dialógico. Para o autor, a base de fundamentação de qualquer proposta de educação deve ocorrer primeiramente tomando-se consciência de que o oprimido carrega dentro de si o opressor. Em seguida, tomando-se consciência de que "ninguém liberta ninguém, ninguém se liberta sozinho: os homens se libertam em comunhão".

Tendo como pilares estes dois pontos, a educação precisa caminhar de maneira dialógica, de modo que o educador seja educado junto com o educando. Com isso, a educação se centra mais no processo de educar com eles, do que sobre eles e para eles. Freire (2006b; p. 58) descreve isto ressaltando:

$$
\begin{aligned}
& \text { Desta maneira, o educador já não é o que apenas } \\
& \text { educa, mas o que, enquanto educa, é educado, em } \\
& \text { diálogo com o educando que, ao ser educado, tam- } \\
& \text { bém educa. Ambos, assim, se tornam sujeitos do } \\
& \text { processo em que crescem juntos e em que os argu- } \\
& \text { mentos de autoridade já não valem. Já agora nin- } \\
& \text { guém educa ninguém, como tampouco ninguém se } \\
& \text { educa a si mesmo: os homens educam em comu- } \\
& \text { nhão, mediatizados pelo mundo. }
\end{aligned}
$$

Ainda, essa pedagogia, ocorreria em dois momentos distintos: no primeiro, os oprimidos vão desvelando o mundo da opressão e comprometendo-se com a práxis, com a sua transformação; e no segundo, uma vez transformada a realidade opressora, essa pedagogia deixa de ser do oprimido e passa a ser dos homens em processo permanente de libertação. Este processo seria a saída para resolver a dialética entre o oprimido-opressor (FREIRE, 2006b). 


\section{HUMANAS}

Porém, o autor ao evidenciar que o processo revolucionário deve ter a educação como centro, ao mesmo tempo, denuncia o perigo desta educação não ser acompanhada de mudanças estruturais, redundar em um idealismo.

Idealistas seríamos se, dicotomizando a ação da reflexão, entendêssemos ou afirmássemos que a simples reflexão sobre a realidade opressora, que levasse os homens ao descobrimento de seu estado de objetos já significasse serem eles sujeitos (FREIRE, 2006b; p. 148).

E ainda continua:

Ao defendermos um permanente esforço de reflexão dos oprimidos sobre suas condições concretas, não estamos pretendendo um jogo divertido em nível puramente intelectual. Estamos convencidos, pelo contrário, de que a reflexão, se realmente reflexão, conduz a prática (FREIRE, 2006b; p. 59).

Por fim, Freire (2006b, 1977; p. 144) conclui que, para uma revolução atingir o sucesso deve ocorrer um equilíbrio entre o plano subjetivo e o objetivo, não uma dicotomia entre a práxis e a reflexão, mas que ação e reflexão ocorram simultaneamente, através de uma dialeticidade entre objetividade e subjetividade.

Se me ponho numa posição idealista, dicotomizando consciência e realidade, submeto esta àquela, como se a realidade fosse constituída pela consciência. Assim, a transformação da realidade se dá pela transformação da consciência. Se me ponho numa posição mecanicista, dicotomizando igualmente consciência e realidade, tomo a consciência como um espelho que apenas reflete a realidade. Em ambos os casos, nego a conscientização que só existe quando não apenas reconheço mas experimento a dialeticidade entre objetividade e subjetividade, realidade e consciência, prática e teoria.

\section{A Economia Solidária}

\subsection{Uma alternativa para as revoluções "traídas"}

Feito este paralelo entre os autores estudados, propomos contextualizar as alternativas indicadas por Marcuse (1968), que seria o fim do trabalho alienante, 


\section{Herbert Marcuse, Paulo Freire e a economia solidária como alternativa emancipatória}

ou melhor, a sua redução, possibilitando a libertação do Eros, conjuntamente com a proposta de Freire (2006), que prevê uma educação do oprimido, que se realize de maneira democrática e dialética entre o educador e o educando.

Retomamos então o projeto da Economia Solidária, como uma alternativa atual para adaptar as propostas de Marcuse (1968) e Freire (1974, 1977, 1983, 2006a, 2006b). A Economia Solidária se fortaleceu a partir da década de 1990, como uma saída para a geração de renda às camadas marginalizadas da sociedade e também como um projeto político alternativo ao sistema capitalista (POCHMANN, 2004). Um dos primeiros autores a definir a Economia Solidária foi Razeto (1999; p. 40), abordando da seguinte maneira:

Concebemos a economia de solidariedade como uma formulação teórica de nível científico, elaborada a partir e para dar conta de conjuntos significativos de experiências econômicas - no campo da produção de comércio, financiamento de serviços etc. - que compartilham alguns traços constitutivos e essenciais de solidariedade, mutualismo, cooperação e autogestão comunitária, que definem uma racionalidade especial, diferente de outras racionalidades econômicas. Trata-se de um modo de fazer economia que implica comportamentos sociais e pessoais novos, tanto no plano da organização da produção e das empresas, como nos sistemas de destinação de recursos e distribuição dos bens e serviços, e nos procedimentos e mecanismo de consumo e acumulação.

Uma definição muito próxima da mencionada é a de Singer (2002; p. 116):

[...] Se refere a organizações de produtores, consumidores, poupadores, etc., que se distinguem por duas especificidades: (a) estimulam a solidariedade entre os membros mediante a prática da autogestão e (b) praticam a solidariedade para com a população trabalhadora em geral, com ênfase na ajuda aos mais favorecidos.

Já Candeias (2005), afirma que seus elementos vão além da proposta de geração de trabalho e renda. Percebem-se algumas iniciativas nas quais predominam valores de gratuidade, da cooperação e da autogestão em contraposição à lógica do individualismo. Além disso, em alguns casos, quando ocorre uma articulação dessas iniciativas econômicas populares com outros atores sociais, contribui-se para a construção de um projeto de desenvolvimento alternativo para a sociedade. 


\title{
HUMANAS
}

Em similaridade com estes autores, Arroyo e Schuch (2006; p. 20) definem Economia Solidária como um projeto de economia organizada a partir do trabalho, e não do capital, que pode ser de pequeno ou de grande aporte, tendo seu giro local ou global. Ainda acrescentam que "ela se estrutura a partir de empreendimentos que operam em qualquer dimensão de alguma forma associativista, como cooperativa ou associação, fórum, grupo, rede, etc." E que "a partir de empreendimentos solidários articulados em redes, surgem mercados solidários, como clubes de troca, atacadão solidário, moeda social e outras intervenções econômicas".

França e Laville (2004; p. 18) ressaltam que a Economia Solidária tem ênfase em um projeto que une a necessidade de suprir as rendas dos trabalhadores com um objetivo de participação da dimensão pública:

[...] A economia solidária tem por objetivo combinar uma dimensão comunitária (mais tradicional) com uma dimensão pública (mais moderna) na sua ação. Isto é particularmente evidente nos casos em que a ação associativista, fortemente baseada nos vínculos comunitários, ataca a resolução de problemas públicos concretos de um bairro.

Por fim pode se recorrer à definição do Fórum Brasileiro de Economia Solidária ( $\mathrm{s} / \mathrm{d}$ ), um órgão formado por diversas entidades públicas, da sociedade civil e movimentos sociais, que define:

\begin{abstract}
Por economia solidária se compreende um projeto emancipatório que não se restringe a mitigar os problemas sociais gerados pela globalização neoliberal, mas trata-se de um projeto de desenvolvimento integral que visa a sustentabilidade, a justiça econômica, social, cultural e ambiental e a democracia participativa. Ela se fundamenta na cultura da cooperação da solidariedade e da partilha, rejeitando as práticas da competição, da exploração e da lucratividade capitalista.
\end{abstract}

Estas tentativas de conceituação da Economia Solidária nos permitem ressaltar alguns pontos em comum: trata-se de um projeto que busca valores de solidariedade; se condensa no coletivo; se estrutura num modelo de gestão autogestionário; se baseia em cooperativas e associações; possui estratégia de produção voltada para as necessidades; tomadas de decisões coletivas; e distribuição de renda e capital eqüitativas. As divergências em relação ao conceito ocorrem 


\section{Herbert Marcuse, Paulo Freire e a economia solidária como alternativa emancipatória}

quando o tema é tratado na perspectiva de ser ou não um projeto de ruptura em relação ao sistema capitalista, e quando se problematiza como estes processos podem ser operacionalizados (pelo Estado ou autônomo por redes solidárias).

Após recorrermos à literatura para conceituar a Economia Solidária, emergiu um questionamento: onde se manifesta hoje, quais são os seus modos de organização, e a quem atinge? Segundo França e Laville (2004), a Economia Solidária manifesta-se através de quatro formas: com o comércio justo ou consumo solidário, as finanças solidárias, os clubes de trocas e os empreendimentos econômicos solidários.

O comércio justo é representado por redes de consumidores que buscam sensibilizar a opinião pública apontando as injustiças das regras de comércio internacional e empreendendo ações junto a grandes instâncias institucionais de decisão em matéria de política e economia. Busca-se consumir produtos, que tenham a preocupação de um desenvolvimento sustentável, gerando empregos e preservando o meio ambiente. Ainda, propõe-se encontrar canais de distribuição para pequenos produtores em geral de produtos agrícolas e artesanais, e organizados em cooperativas, a fim de eliminar ao máximo o número de intermediários entre o produtor e o consumidor. Em síntese, propõem-se melhorias na sociedade via conscientização em relação ao consumo. Como exemplo, tem-se a Alemanha, onde foram criadas pelas redes de consumo solidário patentes para produtos de agricultura orgânica como o café Max Havelaar (FRANÇA \& LAVILLE, 2004; MONTEIRO, s/d).

Já as Finanças Solidárias têm o objetivo de fornecer crédito às pessoas excluídas do sistema bancário a fim de criarem seu próprio emprego. Esta se funda em critérios de utilidade social, ou seja, no financiamento de empreendimentos que visam a coletividade, em um trabalho de luta contra a exclusão, de preservação ambiental, de ação cultural e de desenvolvimento local. Existe também uma preocupação com o acompanhamento efetivo de projetos durante o período de financiamento, para ver se os mesmos seguem estas propostas. Ainda as taxas de juros cobradas pelo fornecimento dos créditos são muito baixas. Há exemplo temos o Banco de Bangladesh, que é um banco não-governamental, que fornece créditos e financiamentos a taxas muito baixas às entidades de base cooperativa e associativa.

Com os mesmos objetivos do Banco de Bangladesh, surgiu em 1998, no Brasil, o Banco Palmas, em Fortaleza-Ceará, localizada numa comunidade da periferia da cidade. Este banco culminou na criação da Rede Brasileira de Bancos Comunitários, que hoje conta com 13 bancos distribuídos em seis Estados. Já na França temos os CIGALEs (Clubs d'Investisseurs pour une Gestion Alternative et Locale de L'Epargne), uma espécie de sociedade de capital de risco solidário de proximidade, e a NEF (Nouvelle Economie Fraternelle), que foi a primeira iniciativa no país de uma sociedade financeira com vocação inteiramente solidária. 


\section{HUMANAS}

Na Holanda, com objetivos semelhantes, temos os Triodos, bancos solidários que visam o fornecimento de créditos aos excluídos. Podemos apontar ainda as diversas cooperativas de crédito espalhadas no país com os mesmos objetivos citados e os fundos rotativos solidários, que assumem práticas culturais informais de empréstimo entre famílias e grupos sociais (FRANÇA \& LAVILLE, 2004).

A terceira forma de manifestação da Economia Solidária é a economia sem dinheiro ou Clubes de Trocas, que são iniciativas que visam à criação de formas alternativas de trocas ou intercâmbios econômicos, em relação às praticadas segundo uma lógica de mercado. Geralmente são situados numa escala local, e se articulam em redes como modo de organização para comprar e trocar produtos, a fim de fazer face ao fenômeno da exclusão social. Existe ainda, uma moeda social, de valor fictício ao do mercado convencional que serve de instrumento de troca de mercadorias no grupo. Como exemplos têmse, o SEL (Systemes d'echanges locaux) na França, o LETS (Local Exchange trading system), nos países anglo-saxônicos, e o REL (Redes de economia Local) na Itália, que são associações de pessoas que visam realizar trocas de bens e serviços, de maneira distinta à forma mercantil, posto que, tais trocas priorizam a permanência das relações sociais. Na França, o SEL foi criado em 1994, e conta hoje com mais de 60.000 pessoas; e na Argentina uma associação semelhante foi criada em 1995, contando com 500.000 argentinos cadastrados em redes, e movimentando aproximadamente quatro bilhões de dólares por ano (FRANÇA \& LAVILLE, 2004, RAIZEIRO \& GABRIELA, s/d).

Por fim os Empreendimentos Econômicos Solidários são as associações, cooperativas, microempresas e empresas solidárias, que se organizam de modo autogestionário, de modo que a rendas e o capital são distribuídos eqüitativamente, e a tomada de decisões é coletiva. Segundo dados de uma pesquisa realizada pelo SIES (2006), existem hoje apenas no Brasil cerca 14.954 Empreendimentos Econômicos Solidários que abrangem 2.274 cidades de todos Estados da federação. E, destes, $54 \%$ se organizam em forma de associações e $11 \%$ em cooperativas.

Os casos citados acima, de modelos de desenvolvimento de Economia Solidária, são apenas alguns exemplos, dentre os vários movimentos que ocorrem em diversas partes do mundo hoje, como uma saída para os problemas do sistema de Economia Mercantil.

\subsection{Arquitetura de um projeto alternativo}

Para tentar estruturar a proposta da Economia Solidária como uma possível saída para as alternativas de Marcuse (1968) e Freire (2006a,b), primeiramente, 


\section{Herbert Marcuse, Paulo Freire e a economia solidária como alternativa emancipatória}

tomaremos como base o modelo de estrutura organizacional adotado em diversos empreendimentos solidários, as cooperativas populares. Segundo o Sies (2006), 40\% dos empreendimentos solidários no Brasil, se organizam por meio de cooperativas populares. Mas, no que se consiste essas cooperativas? Segundo Oliveira (2006), o cooperativismo popular, é considerado um tipo de modelo organizacional que, além de buscar exercitar os princípios básicos e históricos do cooperativismo, se aproxima, exclusivamente, das camadas populares da sociedade, ou seja, daqueles trabalhadores que se encontram em situação precária, e que buscam alternativas de complementação de renda. Ainda, mais do que geração e renda, esta proposta, visa, sobretudo, possibilitar que os trabalhadores atuem de acordo com uma orientação que remeta ao exercício da cooperação e solidariedade, alcançando proteção e mudança social.

Consonante com esta posição, Guimarães (2000), também define o cooperativismo popular como uma prática que ocorre nas camadas populares da sociedade. Estes cooperados realizam a autogestão; elaboram novas formas de produção, consumo e distribuição e almejam um projeto político que os possibilite exercitar a cidadania. Ou seja, trata-se de um modo de organização baseado na distribuição de renda equitativa, no capital socializado entre os membros e na tomada de decisões coletiva.

Rios (1989), ao analisar a estrutura organizacional das cooperativas, questiona "se o cooperativismo pode servir como um projeto socialista". O autor segue a linha de argumentação, perguntando "quais os possíveis componentes de um projeto socialista?". E responde que um projeto socialista deve se basear em três princípios básicos: propriedade dos meios de produção; gestão democrática desses meios; e orientação da produção em função da satisfação das necessidades humanas.

Ainda neste possível projeto socialista, de acordo com o autor, a propriedade de produção trata de algo que deve estar a serviço da coletividade e não de uma tecnocracia estatal ou partidária. E para que se consiga manter esta configuração se deve buscar como método a gestão democrática desses meios, em função das necessidades humanas, e não do lucro, do poder estatal ou partidário. Comparando então, estas premissas básicas com as características de uma organização cooperativa (propriedade, gestão e repartição comuns), Rios (1989; p. 66), conclui que, em tese, "é fácil comprovar como o cooperativismo pode servir a um projeto socialista".

Retomando as propostas de Marcuse (1968) e Freire (1977, 2006b), acreditamos que essas cooperativas podem potencializar a união entre a teoria e a práxis: na teoria, as cooperativas populares se apresentando como alternativa revolucionária (de contraponto à lógica do capital, formada nos valores de solidariedade e coletivismo), e no plano das práxis, estruturando-se por uma mudança organizacional (divisão equitativa dos bens, capital socializado, decisões coletivas). 


\section{HUMANAS}

Contudo, aos tratarmos desta proposta, estamos levando em consideração também as críticas de Guillerm e Bourdet (1976; p. 53), que relataram a impossibilidade das cooperativas serem "autogestionárias", posto que inseridas no sistema capitalista.

[...] No principio, não há diferença entre cooperativa e autogestão, mas, historicamente, aparece uma diferença de natureza: a extensão ou, antes, a generalização do sistema cooperativo não se pode fazer sem abolir o Estado, substituído por uma organização nacional de tipo radicalmente menor.

Ou seja, as cooperativas e associações isoladas não podem romper com a lógica do capital, visto que necessitam produzir e vender seus produtos e serviços para sobreviver. Ainda necessitam competir com empresas capitalistas dentro do mercado e isto exige delas modelos e estruturas de gestão eficientes, como a divisão do trabalho, a hierarquia de funções, bem como tomadas de decisões rápidas, centralizadas nas diretorias. Conseqüentemente, tais modelos ainda continuam reproduzindo as estruturas de alienação e dominação.

Diante desta limitação, defendemos como uma alternativa a estruturação das cooperativas por meio de redes solidárias. As redes solidárias são conglomerados de diversas cooperativas e associações de vários setores produtivos e de consumo, que compram matérias primas e vendem seus produtos para as outras cooperativas. Ainda, as mercadorias são trocadas do mesmo modo que ocorrem nos clubes de troca, com a criação de uma moeda social, desvinculada dos laços financeiros, inflações e deflações (MANCE, 1999; FRANÇA, 2008).

Neste cenário, torna-se necessário também, potencializar os bancos solidários, para financiar a criação de novos empreendimentos solidários. Essa estrutura pode permitir que a produção caminhe de acordo com os interesses coletivos e as decisões, do que produzir e quanto produzir, sejam tomadas de modo democrático, em assembléias pelos membros da rede.

Como exemplo deste modelo de rede solidária, podemos citar o Banco de Palmas (na cidade de Fortaleza), que envolve mais de 20.000 pessoas, e se organiza nos moldes de acordo com esta lógica, contando com diversas cooperativas e associações, bancos solidários e até mesmo uma moeda social, como facilitador de troca de mercadorias. Há também o caso da Central de Cooperativas Sociais do Estado de Lara (Cecosesola) na Venezuela: trata-se de uma rede de cooperativas, que existe há 44 anos e envolve mais 40.000 pessoas, 


\section{Herbert Marcuse, Paulo Freire e a economia solidária como alternativa emancipatória}

sendo constituída por diversos empreendimentos solidários, nos quais as decisões de produção e políticas são realizadas por todos os integrantes, por meio de assembléias gerais.

Tais redes (Banco de Palmas, Cecosesola), se mostram próximas do que acreditamos ser um modelo organizacional, que contemple as propostas de Freire e Marcuse. Contudo, estas ainda se encontram isoladas de outras redes, não conseguindo manter todo o controle da cadeia produtiva de seus bens, de modo que não tem outra alternativa a não ser realizar concessões às organizações da sociedade capitalista. Ainda assim, estas constituem um conjunto social de grupos autônomos, associados tanto nas suas funções econômicas de produção, quanto nas funções políticas, formando um grupo social organicamente autônomo e sem hierarquização (MOTTA, 1981).

Proudhon, já ressaltava que uma proposta de autogestão não pode se limitar a um simples modo de gestão de empresas pelo seu pessoal, ou seja, assim como cooperativas e associações isoladas não conseguem romper com a lógica heterogestionária, uma rede solidária isolada também não. Nesta mesma perspectiva Novaes (2008; p. 12), relata que os empreendimentos solidários hoje se limitam ao tema de decisões democráticas "dentro dos muros" de cooperativas populares, associações de trabalhadores e fabricas recuperadas, sem no entanto, realizar uma crítica e analisar os mecanismos de mercado. Este fato faz com que os trabalhadores se limitem apenas às decisões coletivas da empresa, sem observar a permanência da perda do controle do produto do trabalho. Ainda, os mesmos, por não vislumbrarem a coordenação global pelos produtores associados, estão atribuindo uma nova roupagem a uma velha proposta socialista de mercado. O autor ainda ressalta que para Proudhon "[...] emancipar o operário-artesão da dominação do dinheiro (do capital), sem abolir a produção mercantil e a concorrência: (é uma) ilusão tipicamente artesanal pequeno-burguesa".

Desta maneira, Novaes (2008; p. 18) conclui que "a questão fundamental é o controle global dos do processo de trabalho pelos produtores e não simplesmente a questão de como subverter os direitos de propriedade estabelecidos".

Para nós, este controle global, tem sua força na constituição das redes solidárias integradas, se intercomunicando, e decidindo o que e quanto produzir coletivamente. Assim o controle da produção conforme os interesses sociais e não do mercado, pode limitar a concorrência e, conseqüentemente, a incessante busca pela eficiência para a lucratividade. Tal fato ainda pode abrir espaço para uma redução das jornadas de trabalho, possibilitando um maior tempo livre para os indivíduos. Desta maneira, pode se ter espaço para trabalhar na rotatividade dos cargos, e na redução das hierarquias, posto que nestas condições todos são donos do capital. Esses fatores podem levar então à redução da alienação no trabalho, como proposta por Marcuse (1968). 


\section{HUMANAS}

Este novo contexto, desvinculado das exigências do mercado e conseqüentemente, distante das mediações de primeira e segunda ordem ${ }^{7}$ pode criar um ambiente propício para uma educação dialógica entre os membros, mantendo a dialética objetividade-subjetividade, teoria e prática, proposta por Freire (1977, 2006, 2006b). Contudo este processo de educação, para nós deve ocorrer nas cooperativas e associações, antes mesmo destas se constituírem em redes, para assim evitar a formação dos "líderes libertadores" e a equivocada tese de que a educação deve suceder revolução.

Acreditamos também que alguns pontos centrais devem ser levados em consideração nesta proposta pedagógica, tomando como referência as sugestões de Freire e Marcuse: esta educação precisa focalizar os valores de solidariedade, as denúncias das desigualdades sociais, a análise crítica da lógica de produção e de consumo do sistema capitalista, a ressignificação de modelos de gestão adequados a este novo modo de estrutura organizacional (autogestão), e a importância de se realizar uma autocrítica de todo este programa político. E a quem cabe esta tarefa, de fomentar a educação? Para nós, os próprios membros das redes solidárias, os integrantes movimentos sociais e de outros grupos autônomos críticos da lógica de produção capitalista, que acreditem no princípio de que todos são educadores e educandos, dentro de um processo dialético de trocas de conhecimentos e experiências.

\section{Considerações Finais}

Tendo como objetivo compreender o "fracasso" das revoluções, nas concepções de Freire e Marcuse, recorreu-se primeiramente à obra Eros e civilização de Marcuse (1968), e observou-se que a causa do problema surgiu pelos fatores subjetivos, com a introjeção das atitudes do pai opressor nos filhos e se propagou até hoje por meio do trabalho alienado, que impossibilita uma reflexão crítica de alternativa revolucionária. Para isto, o autor propôs que a saída deve surgir primeiramente pela abolição do trabalho alienado e de qualquer possibilidade que reative a personalidade reprimida e produtivista. Ainda, se faz necessária redução da divisão do trabalho, a ausência de funções institucionalizadas e hierarquias, a diminuição do tempo de trabalho e a permutabilidade de funções.

Já Freire (2006b), ao buscar uma causa para as revoluções traídas, caminhou na mesma perspectiva de Marcuse (1968), defendendo a tese que os oprimidos carregam dentro de si o opressor. E que o medo de expulsar o opressor de si,

\footnotetext{
${ }^{7}$ As mediações de segunda ordem envolvem a propriedade privada, intercâmbio e a divisão do trabalho, que são aspectos que se interpõem entre o homem e sua atividade e o impedem de se realizar em seu trabalho, no exercício de suas capacidades produtivas (criativas) e na apropriação humana dos produtos de sua atividade. Trata-se de uma mediação da mediação, nascida da mediação de primeira ordem, que é a atividade produtiva como um tal (MESZAROS, 2006).
} 


\section{Herbert Marcuse, Paulo Freire e a economia solidária como alternativa emancipatória}

reproduz as atitudes não dialógicas que minam as revoluções. Para o autor, contudo, a alternativa deve partir de uma educação dialógica entre revolucionários e massas oprimidas, possibilitando ainda a permanência da dialética entre teoria e práxis.

Feitas estas considerações, tomamos à Economia Solidária como uma alternativa para condensar as propostas de Marcuse (1968) e Freire (1977, 2006a, 2006b). Aqui, defendemos que a estrutura organizacional autogestionária das cooperativas e associações pode possibilitar um ambiente propício para um "projeto socialista". Contudo, acreditamos que este se potencializa, levando em consideração a estrutura organizacional de redes solidárias, que pode reduzir a concorrência entre as cooperativas e possibilitar a implementação de uma educação dialógica e a redução da alienação. Vale observar que ao utilizarmos tal "arquitetura" não estamos fechando o debate há um simples e único receituário, mas acreditamos que esta proposta possa ser uma das possíveis alternativas de se constituir uma nova sociedade, pautadas nas reflexões de Freire e Marcuse.

Contudo, também não ignoramos que este movimento, que brota em diversas partes do mundo, se encontra repletos de limitações: (a) estruturais por meio de divisão do trabalho, constituição de hierarquias, jornadas que excedem o tempo convencional, formação de quadros administrativos, decisões centralizadas nos "mais experientes"; (b) no posicionamento dos membros - com a permanência do individualismo nas atitudes na distribuição de sobras e de tarefas e o desinteresse por participar das decisões; (c) nos processos de gestão - com a dificuldade de re-significar o conhecimento ou o uso da técnica para o novo contexto autogestionário; com isso, em busca da eficiência se reproduzem instrumentos técnicos para a coordenação da cooperativa; (d) de formação política - com a ausência de fomento, ou debate sobre os valores da Economia Solidária, como o cooperativismo, o associativismo, a alienação, as relações de poder no trabalho, bem como propostas de articulação de contraponto ao capitalismo; (e) em um processo de naturalização da opressão - com a permanência e reprodução do discurso de que a sociedade sempre se estruturou de maneira hierárquica, e que o fato de haver desigualdade na distribuição de rendas e tomada de decisões se deve à falta de capacitação e conhecimento do indivíduo; (e) de um seqüestro do imaginário - na impossibilidade de se pensar em algo que transcenda o sistema capitalista, visto que se acredita que ele é "dominante" e o sujeito não tem voz, nem vez. Nega-se com isto a possibilidade de se criar utopias.

Assim, a proposta de uma mudança radical, ou abertura para novas revoluções de cunho social, via Economia Solidaria, se mostra diante de um árduo terreno de desafios e limites a serem superados. Contudo, ainda sim queremos acreditar neste projeto, como uma possível saída de luta contra-hegemônica à lógica capitalista, por meio de uma revolução pacífica em ação, que não se propõe centrar na mudança pelo uso da força. 


\section{HUMANAS}

O estranho mito de que a ferida aberta só pode ser sarada pela arma que praticou a ferida ainda não foi validado na História: a violência que deflagra a cadeia de violência pode dar início a uma nova cadeia (MARCUSE, 1968; p. 20).

\section{Referências bibliográficas}

ADORNO, T. Televisão, consciência e indústria cultural. In: G. COHN. Comunicação e indústria cultural. São Paulo: Companhia Editora Nacional, 1978.

ARROYO, J. \& SCHUCH, F. Economia popular e solidária: a alavanca para um desenvolvimento sustentável e solidário. São Paulo: Editora Fundação Perseu Abramo, 2006.

BENJAMIN, W. A Obra de arte na época de sua reprodutibilidade técnica. In: L. LIMA. Teoria da cultura de massa. Rio de Janeiro: Paz e Terra, 1982.

CANDEIAS C. Economia solidária e autogestão: ponderações teóricas e achados empíricos. Maceió: EDUFAL, 2005.

Fórum Brasileiro de Economia Solidária. Carta de Princípios, s/d. Disponível em http://www.fbes.org.br (acesso: 15 Jan/2009).

FRANÇA F. A via sustentável solidária no desenvolvimento local. $O \& S$. v.15, n. $45,2008$.

FRANÇA F. \& LAVILLE J. A economia solidária: uma abordagem internacional. Porto Alegre: Editora UFRGS, 2004.

FREIRE, P. Las iglesias, la educacion y el proceso de liberacion humana en la historia. Buenos Aires: La Aurora, 1974.

FREIRE, P. Ação cultural para a liberdade e outros escritos. Rio de Janeiro: Paz e Terra, 1977.

FREIRE, P. Extensão ou comunicação? Rio de Janeiro: Paz e Terra, 1983.

FREIRE, P. A importância do ato de ler: três artigos que se completam. São Paulo: Cortez, 2006a.

FREIRE, P. Pedagogia do oprimido. Porto Alegre: Artmed, $2006 \mathrm{~b}$.

GUILLERM, A. \& BOURDET, Y. Autogestão: uma mudança radical. Rio de Janeiro: Zahar, 1976. 


\section{Herbert Marcuse, Paulo Freire e a economia solidária como alternativa emancipatória}

D. Calbino \& A.P.P. de Paula

GUIMARÃES, G. Incubadoras tecnológicas de cooperativas populares: contribuição para um modelo alternativo de geração de trabalho e renda. In: P. SINGER \& A. SOUZA (Orgs.). A economia solidária no Brasil: a autogestão como resposta ao desemprego. p. 111-22. São Paulo: Contexto. 2000.

HORKHEIMER, M. \& ADORNO, T. A indústria cultural - o iluminismo como mistificação das massas (1947). In: J.M.B. ALMEIDA (Org.). Indústria cultural e sociedade: Theodor Adorno. São Paulo: Paz e Terra, 2007.

MANCE, E.A. A revolução das redes: a colaboração solidária como uma alternativa pós-capitalista à globalização atual. Petrópolis: Vozes, 1999.

MARCUSE, H. Eros e civilização. Uma interpretação filosófica do pensamento de Freud. Rio de Janeiro: Zahar editores, 1968.

MESZAROS, I. A teoria da alienação em Marx. São Paulo: Boitempo, 2006.

MONTEIRO, C. Como funciona o comercio justo? (s/d). Disponível em: http://empresasefinancas.hs²w.uol.com.br (Acesso: 15 Jan/2009).

MOTTA, P.F. Burocracia e autogestão - a proposta de Proudhon. São Paulo: Brasiliense, 1981.

NOVAES, H. Qual autogestão? Revista Soc. Bras. Economia Política, 2008.

OLIVEIRA, B. As cooperativas populares e seus desafios, limites e possibilidades: casos de cooperativas da cidade do Rio de Janeiro. Tese de Doutoramento. Rio de Janeiro: Universidade Federal Rural do Rio de Janeiro, 2006.

POCHMANN, M. Economia Solidária no Brasil: possibilidades e limites. Mercado de Trabalho/IPEA, 24 Agosto, p. 23-34, 2004.

RAZETO, L. Economia de solidariedade e organização popular. In: M. GADOTTI \& F. GUTIERREZ (Orgs.). Educação comunitária e economia popular. p. 34-58. São Paulo: Cortez, 1999.

RAIZEIRO, A. \& GABRIELA, M. Trocas Solidárias, s/d. Disponível em: http://www.geranegocio.com.br. (Acesso: 16 Jan/2009.

RIOS, G. O que é cooperativismo. São Paulo: Brasiliense, 1987.

SIES - Sistema Nacional de Informações em Economia Solidária, 2005. Atlas da Economia solidária no Brasil. Brasília: MTE/SENAES, 2006.

SINGER, P. Introdução à economia solidária. São Paulo: Fundação Perseu Abramo, 2002. 